\title{
FDI and Economic Growth \\ Relationship: An Empirical Study on Malaysia
}

\author{
Har Wai Mun \\ Faculty of Accountancy and Management \\ Universiti Tunku Abdul Rahman \\ Bander Sungai Long \\ 43000 Selangor, Malaysia \\ Email: harwm@mail.utar.edu.my \\ Teo Kai Lin \\ Faculty of Accountancy and Management \\ Universiti Tunku Abdul Rahman \\ Bander Sungai Long \\ 43000 Selangor, Malaysia \\ Yee Kar Man \\ Faculty of Accountancy and Management \\ Universiti Tunku Abdul Rahman \\ Bander Sungai Long \\ 43000 Selangor, Malaysia
}

\begin{abstract}
Foreign direct investment (FDI) has been an important source of economic growth for Malaysia, bringing in capital investment, technology and management knowledge needed for economic growth. Thus, this paper aims to study the relationship between FDI and economic growth in Malaysia for the period 1970-2005 using time series data. Ordinary least square (OLS) regressions and the empirical analysis are conducted by using annual data on FDI and economy growth in Malaysia over the 1970-2005 periods. The paper used annual data from IMF International Financial Statistics tables, published by International Monetary Fund to find out the relationship between FDI and economic growth in Malaysia case. Results show that LGDP, LGNI and the LFDI series in Malaysia are I(1) series. There is sufficient evidence to show that there are significant relationship between economic growth and foreign direct investment inflows (FDI) in Malaysia. FDI has direct positive impact on RGDP, which FDI rate increase by $1 \%$ will lead to the growth rate increase by $0.046072 \%$. Furthermore, FDI also has direct positive impact on RGNI because when FDI rate increase by $1 \%$, this will lead the growth increase by $0.044877 \%$.
\end{abstract}

Keywords: Growth, FDI inflows, FDI and growth relationship, Malaysia's economy

\section{Introduction}

This paper defines foreign direct investment (FDI) as international capital flows in which a firm in one country creates or expands a subsidiary in another. It involves not only a transfer of resource but also the acquisition of control. Since the 1990s, FDI has been a source of economic growth for Malaysia, believing that besides needed capital, FDI brings in several benefits. The most important benefit for a developing country like Malaysia is that FDI could create more employment. In addition, technology transfer is another benefit for the host countries. When the foreign factories are set up in their countries, they will expose to higher technology production and efficiency in management. Once in future, they able to produce goods and services as competitive as foreigners do. Nevertheless, insufficient funds for investment are the main reason to seek FDI. Usually many less-developed countries lack of fund for investment. Foreign direct 
investment can help them to develop their country and improve their standard of living by creating more employment. According to Mohd Nazari Ismail (2001), he finds that foreign direct investment play a significant role in the Malaysian economy especially in the electronic industry. In addition to creating more jobs and generating export,the foreign multinationals have also contributed to the development of the technical capabilities of the locals. This is through the process of technology transfer.

\section{Trends and Patterns of FDI Flow in Malaysia}

Figure 1 presents the trend of FDI inflow to Malaysia, during 1970 to 2004 . For the past two decade, Malaysia was receiving a lot FDI. FDI stock in Malaysia starts to grow up slowly by 1970s. FDI inflows had increased almost twenty-fold during 1970s to 1990s, from $\$ 94$ million dollar in 1970s to $\$ 2.6$ billion dollar by 1990s, although there was some fluctuation between the years. Even though the FDI was increased over the year, however, since the early of 1990s, there have been several periods of slowdown. In 1993, FDI drop drastically dropped drastically due to a slowdown in investments from two main sources of investments for Malaysia - Japan and Taiwan. One of the main reasons for this slowdown is the rise in wage rates in Malaysia relative to other Asian countries (such as China, Vietnam and Indonesia). The total FDI flows in Malaysia was peaked at 1996, when it achieve \$7.3 billion dollar. The financial crisis of 1997 that affected most of the Southeast Asia also serves to reduce FDI into Malaysia. Since the early of 2000s, the FDI flows in Malaysia tend to inconsistent and fluctuate randomly, however it also achieve an average inflows of US\$3billion per year.

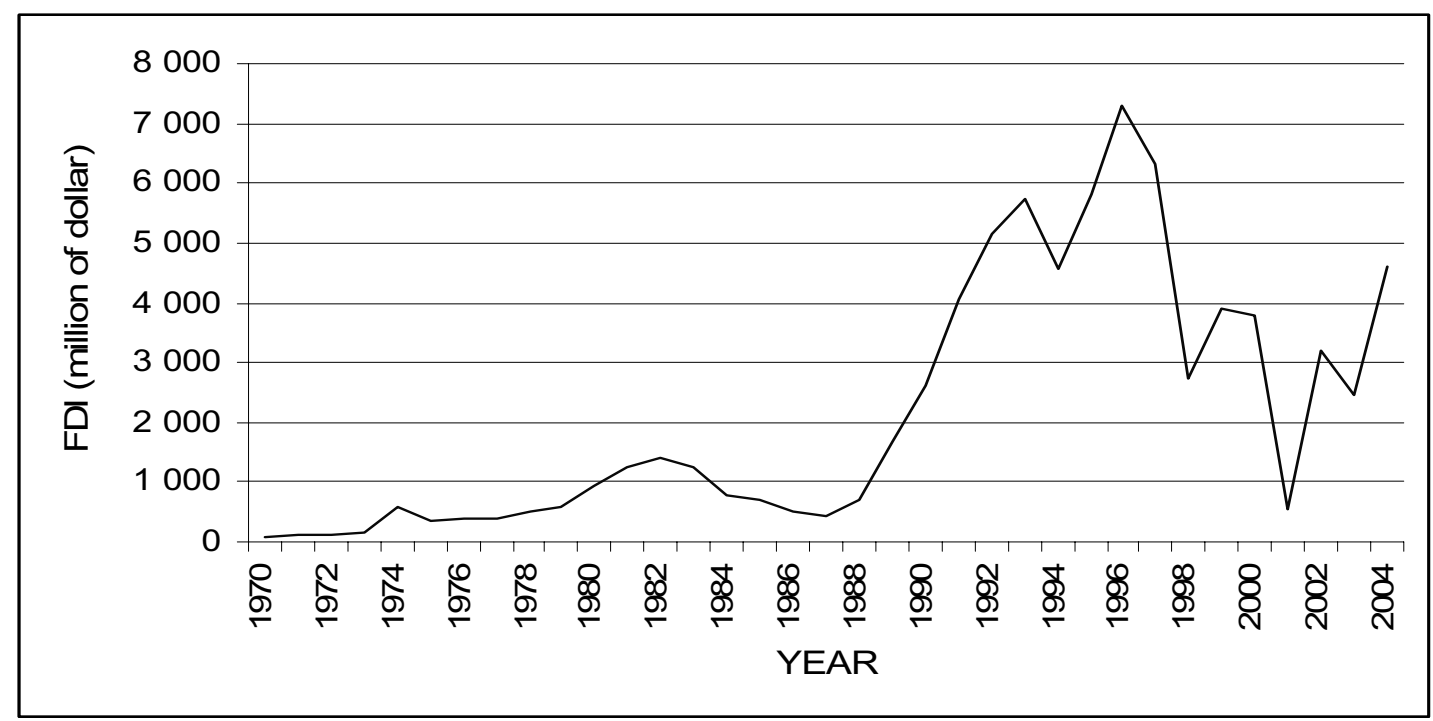

Figure 1. FDI Inflows to Malaysia, (in million dollars) 1970-2004

Source: United Nations Conference on Trade and Development (UNCTAD), various issues.

In general, Malaysia is the second fastest growing economy in the South East Asian region with an average Gross National Product (GNP) growth of eight-plus percent per year in the last seven years. Since independence in 1957, Malaysia has moved from an agriculturally based economy to a more diversified and export oriented one. The Malaysian market is fairly openly oriented, with tariffs only averaging approximately fifteen percent and almost non-existent non-tariff barriers and foreign exchange controls. With a stable political environment, increasing per capita income, and the potential for regional integration throughout the Association of South East Asian Nations (ASEAN), Malaysia is an attractive prospect for FDI.

The key success factor of the FDI contributes to the economic growth in Malaysia because of the good environment. If the environment not suitable, it will not encourage foreign investors come to invest. Good favorable conditions make investors face fewer problems because all investors can run their business conveniently in order to make more profit with life safety. Few vital clues for foreign direct investment include political stability, economic stability, lower wages, and easy accessibility to plentiful raw material, special rights, and person safety.

Long term political stability makes foreign investors confident with theirs businesses will succeed and remain profitable. Besides, economic instability like inflation, foreign exchange fluctuation and economic crisis also another important environment factor for investor to consider because can cause the business lose without knowing in advance.

Furthermore, foreign investors try to search the country with lower wages to reduce average cost of production and hence strongly persuade foreigners to invest in that country. A country with plenty of raw materials necessary for the production attracts investors more than a country without it and personal safety also vital to foreign investors because 
life is more valuable than money, nobody like to take risk as being killed or kidnapped in foreign country.

\section{Objective of Study}

The main objective in this paper, therefore aims to study the relationship between FDI and economic growth in Malaysia for the period 1970-2005 using time series data. The rest of the paper is structured as follow: Section 2, there will have review on the empirical literature done on FDI and economic growth. Section 3 will be the data and methodology. Section 4 will be the result and interpretation and finally is Section 5 will be the findings from this study.

\section{Literature Review}

Foreign direct investment (FDI) has played a leading role in many of the economies of the region. There is a widespread belief among policymakers that foreign direct investment (FDI) enhances the productivity of host countries and promotes development. There are several studies done on FDI and economic growth. Some of the studies testing the relationship between FDI and economic growth while some are find out the causality between two variables. Their findings are varies from different method use on their research such as some of the researchers found that FDI has a positive effect on economic growth. For example is Balasubramanyam et al (1996) analyses how FDI affects economic growth in developing economies. Using cross-section data and OLS regressions he finds that FDI has a positive effect on economic growth in host countries using an export promoting strategy but not in countries using an import substitution strategy.

Olofsdotter (1998) provides a similar analysis. Using cross sectional data she finds that an increase in the stock of FDI is positively related to growth and that the effect is stronger for host countries with a higher level of institutional capability as measured by the degree of property rights protection and bureaucratic efficiency in the host country. Besides that, Borensztein et.al (1998) examine the effect of foreign direct investment(FDI) on economic growth in a cross country regression framework, utilizing data on FDI flows from industrial countries to 69 developing countries over the last two decades. Their outcome of this study is that FDI is an important vehicle for the transfer of technology, contributing relatively more to growth than domestic investment. However, the higher productivity of FDI holds only when the host country has a minimum threshold stock of human capital. Thus, FDI contributes to economic growth only when a sufficient absorptive capability of the advanced technologies is available in the host economy. Another study based on developing economies is Borensztein et al (1998) that examines the role of FDI in the process of technology diffusion and economic growth. The paper concludes that FDI has a positive effect on economic growth but that the magnitude of the effect depends on the amount of human capital available in the host country. In contrast to the preceding studies, De Mello (1999) only finds weak indications of a positive relationship between FDI and economic growth despite using both time series and panel data fixed effects estimations for a sample of 32 developed and developing countries.

On the other hand, Zhang (2001) and Choe (2003) analyses the causality between FDI and economic growth. Zhang uses data for 11 developing countries in East Asia and Latin America. Using cointegration and Granger causality tests, Zhang (2001) finds that in five cases economic growth is enhanced by FDI but that host country conditions such as trade regime and macroeconomic stability are important. According to the findings of Choe (2003), causality between economic growth and FDI runs in either direction but with a tendency towards growth causing FDI; there is little evidence that FDI causes host country growth. Rapid economic growth could result in an increase in FDI inflows.

There is further study done by Chowdhury and Mavrotas (2003) which examine the causal relationship between FDI and economic growth by using an innovative econometric methodology to study the direction of causality between the two variables. The study involves time series data covering the period from 1969 to 2000 for three developing countries, namely Chile, Malaysia and Thailand, all of them major recipients of FDI with different history of macroeconomic episodes, policy regimes and growth patterns. Their empirical findings clearly suggest that it is GDP that causes FDI in the case of Chile and not vice versa while for both Malaysia and Thailand, there is a strong evidence of a bi-directional causality between the two variables. The robustness of the above findings is confirmed by the use of a bootstrap test employed to test the validity of the result. In addition, Frimpong and Abayie (2006) examine the causal link between FDI and GDP growth for Ghana for the pre and post structural adjustment program (SAP) periods and the direction of the causality between two variables.

Annual time series data covering the period from 1970 to 2005 was used. The study finds no causality between FDI and growth for the total sample period and the pre-SAP period. FDI however caused GDP growth during the post -SAP period.

Finally, Bengoa and Sanchez-Robles (2003) investigate the relationship between FDI, economic freedom and economic growth using panel data for Latin America. Comparing fixed and random effects estimations they conclude that FDI has a significant positive effect on host country economic growth but similar to Borensztein et al (1998) the magnitude depends on host country conditions. Carkovic and Levine (2002) use a panel dataset covering 72 developed and developing countries in order to analyse the relationship between FDI inflows and economic growth. The study 
performs both a cross-sectional OLS analysis as well as a dynamic panel data analysis using GMM. The paper concludes that there is no robust link running from inward FDI to host country economic growth.

\section{Data and Methodology}

This section describes the econometrics methods that we use to access the relationship between FDI and economic growth. We use simple ordinary least square (OLS) regressions and the empirical analysis is conducted by using annual data on FDI and economy growth in Malaysia over the 1970-2005 periods. We use annual data from IMF International Financial Statistics tables, published by International Monetary Fund to find out the relationship between FDI and economic growth in Malaysia case.

\subsection{OLS framework}

$$
\text { Growth }_{\mathrm{i}}=\alpha+\beta \mathrm{FDI}_{\mathrm{i}}+\varepsilon_{\mathrm{i}}
$$

Where the dependent variable, Growth, equals to real GDP growth or real GNP growth, and FDI is gross private capital inflows to a country. We use both GDP and GNP for dependent variables in order to test the robustness of the findings. From the equation above, the positive sign of coefficient for FDI represent that there is positive relationship between FDI and economy growth. If there is an increase in FDI inflow, there will led and enhance the economic growth in Malaysia. In contrast, if the FDI is negative correlation to economic growth, it will not help in GDP growth in a country. The hypothesis is stated as below

Hypothesis 1:

$\mathrm{H}_{0}: \beta=0$

$\mathrm{H}_{1}: \beta \neq 0$

The null hypothesis $\beta=0$ (there are no relationship between foreign direct investment (FDI) and real gross domestic production (RGDP) ) or real Gross National Income(RGNI) against its alternative $\beta \neq 0$, if less than lower bound critical value (0.05), then we do not reject the null hypothesis. Conversely, if the t-statistic value greater than 5 percent critical value, then we reject the null hypothesis and conclude that there are significant relationship between independent variable and dependent variable.

\subsection{Diagnostic Testing}

On the other hand, we also apply the diagnostic testing to test the series whether the series are free from autocorrelation, heteroscedasticity and normality problem.

Hypothesis 2:

$\mathrm{H}_{0}$ : There are autocorrelation between members of series of observations ordered in time.

$\mathrm{H}_{1}$ : There are not autocorrelation between members of series of observations ordered in time.

Hypothesis 3:

$\mathrm{H}_{0}$ : There are constant variances for the residual term.

$\mathrm{H}_{1}$ : There are no constant variance for the residual term.

The null hypothesis from hypothesis two and three are do not existing autocorrelation and heteroscedasticity against its alternative do existing autoregression and heteroscedasticity. If the computed p-value is greater than 0.05 significant levels, then we do not reject the null hypothesis and conclude that there does not existing autocorrelation and heteroscedasticity. Conversely, if the computed p-value is less than 0.05 significant levels, the we reject the null hypothesis and conclude that there are existing autocorrelation and heteroscedasticity problem.

\subsection{Unit Root Test}

The first step of constructing a time series data is to determine the non-stationary property of each variables, we must test each of the series in the levels (log or real GDP or GNP and log of FDI) and in the first difference (growth and FDI rate).

First, the ADF test with and without a time trend. The latter allows for higher autocorrelation in residuals. That is, consider an equation of the form:

$$
\Delta \mathrm{X}_{\mathrm{t}}=\beta_{1}+\pi_{1} \mathrm{X}_{\mathrm{t}-1}+\sum_{i=1}^{n} \rho_{1} \Delta \mathrm{X}_{\mathrm{t}-\mathrm{i}}+\mathrm{e}_{1 \mathrm{t}}
$$

However, as pointed out earlier, the ADF tests are unable to discriminate well between non-stationary and stationary series with a high degree of autoregression.

In consequences, the Phillips -Perron (PP) test (Phillips and Perron, 1988) is applied. The PP test has an advantage over 
the ADF test as it gives robust estimates when the series has serial correlation and time-dependent heteroscedasticity. For the PP test, estimate the equation as below:

$$
\Delta \mathrm{X}_{\mathrm{t}}=\alpha+\pi_{2 \mathrm{Xt}-1}+\varphi\left(\mathrm{t}-\frac{T}{2}\right)+\sum_{i=1}^{m} \varphi_{\mathrm{i}} \Delta \mathrm{X}_{\mathrm{t}-\mathrm{i}}+\mathrm{e}_{2 \mathrm{t}}
$$

In both equations (ii) and (iii), $\Delta$ is the first difference operator and $\mathrm{e}_{1 \mathrm{t}}$ and $\mathrm{e}_{2 \mathrm{t}}$ are covariance stationary random error terms. The lag length $\mathrm{n}$ is determined by Akaike's Information Criteria (AIC) (Akaike,1973) to ensure serially uncorrelated residuals (for PP test) is decided according to Newley-West's (Newley and West, 1987) suggestions.

Hypothesis 4:

$\mathrm{H}_{0}$ : Series contains a unit root

$\mathrm{H}_{1}$ : Series is stationary

In ADF and Phillips Perron tests, the null hypothesis of non-stationarity is tested the t-statistic with critical value calculated by MacKinnon (1991). The outcome suggests that reject null hypothesis which can conclude the series is stationary. Both ADF and PP test are applied following Engle and Granger (1987) and Granger (1986) and subsequently supplemented by the PP test following West (1988) and Culver and Papell(1997).

Besides that, Kwiatkowski, Phillips, Schmidt, and Shin (1992) introduce such a test, and do it by choosing a component representation in which the time series under study is written as the sum of a deterministic trend, a random walk, and a stationary error. The null hypothesis of trend stationary corresponds to the hypothesis that the variance of the random walk equals zero. As one could expect, their results are frequently supportive of the trend stationarity hypothesis contrary to those traditional unit root tests.

Hypothesis 5:

$\mathrm{H}_{0}$ : Series is stationary

$\mathrm{H}_{1}$ : Series contains a unit root

In KPSS test, the null hypothesis of stationarity is tested. The outcome suggests that do not reject hypothesis, which can conclude the series is stationary. Besides, testing for stationarity is so important in time series data is to avoid spurious regression problem and violate of assumption of the Classical Regression Model.

\section{Results and interpretation}

Economic growth rates (y) are calculated in logs of real gross domestic product (GDP) or gross national income (GNI). Likewise, FDI equals to FDI inflows as a share of GDP are calculated in the logarithms form respectively for Malaysia. The empirical results are reported in three steps. First we test for the order of integration for both GDP and FDI in Malaysia. In the second step, we difference the data to test the relationship between FDI and economic growth to avoid spurious regression problem. Finally, we conduct the simple Ordinary Least Square (OLS) test to seek the relationship between FDI and economic growth in Malaysia. To stage the unit root test, the order of integration of the variables is initially determined using the Augmented Dickey-Fuller (ADF) tests. The unit root tests are performed sequentially. The result show that LGDP or LGNI and the LFDI series in Malaysia are I(1) series. The null hypothesis of a unit root is not rejected. To check the robustness of the ADF test results, Phillip-Perron test and KPSS test are applied. The results are shown in Table 1 and 2 on the level form and first difference form. Given the results of the ADF and Phillips Perron tests, it is concluded that all variables in this study are integrated of order one except for KPSS test, all variables are not stationary at first difference since the limitation of the data collection, so the results from KPSS test are not consistent with the ADF and Phillip Perron test. These three unit root tests are employed to make any estimated relationship between the growth and FDI inflow for Malaysia would not be spurious.

Table 1. Results for Natural Logarithms of RGDP

\begin{tabular}{|l|l|l|l|l|l|l|}
\hline \multicolumn{7}{|c|}{$\begin{array}{l}\text { Augmented Dickey-Fuller, Phillips-Perron and KPSS tests } \\
\text { for unit root on the natural logarithms of RGDP, RGNI and FDI of Malaysia } \\
\text { for the period 1970-2005 }\end{array}$} \\
\hline & \multicolumn{7}{|c|}{ with trend } & \multicolumn{4}{c|}{ without trend } \\
\hline Variable & ADF & PP & KPSS & ADF & PP & KPSS \\
\hline RGDP & $-3.2278(2)^{* * *}$ & -2.3349 & 0.0606 & $-0.5427(1)$ & -0.5390 & $0.7534^{*}$ \\
\hline RGNI & $-1.1915(1)$ & -2.3213 & $0.0595^{*}$ & $-1.1915(1)$ & -0.4771 & $0.7536^{*}$ \\
\hline FDI & $-1.7764(1)$ & -2.9309 & 0.0883 & $-1.7764(1)$ & -1.6890 & $0.5656^{* * *}$ \\
\hline
\end{tabular}


Table 2. Results for natural First Difference of RGDP

\begin{tabular}{|l|l|l|l|l|l|l|}
\hline \multicolumn{7}{|c|}{$\begin{array}{l}\text { Augmented Dickey-Fuller, Phillips-Perron and KPSS tests } \\
\text { for unit root on the first difference of RGDP, RGNI and FDI of Malaysia } \\
\text { for the period 1970-2005. }\end{array}$} \\
\hline & \multicolumn{5}{|c|}{ with trend } & \multicolumn{3}{c|}{ without trend } \\
\hline Variable & ADF & PP & KPSS & ADF & PP & KPSS \\
\hline RGDP & $-5.6050(1)^{*}$ & $-5.6050^{*}$ & 0.0586 & $-5.5760(1)^{*}$ & $-5.5760 *$ & 0.0644 \\
\hline RGNI & $-5.1337(1)^{*}$ & $-5.1382 *$ & 0.0533 & $-5.1337(1)^{*}$ & $-5.1480 *$ & $0.0560 * *$ \\
\hline FDI & $-7.2547(2)^{*}$ & $-7.2691 *$ & 0.0602 & $-7.3832(2)^{*}$ & $-7.5855^{*}$ & 0.0606 \\
\hline
\end{tabular}

For instance, to test the relationship between FDI inflow and growth, ordinary least square (OLS) method is used to estimate it.

Estimate Model for the Malaysia Growth Function:

I) Estimate Model

Dependent variable: $\triangle \mathrm{LRGDP}$

\begin{tabular}{|l|l|l|}
\hline Variable & Coefficient & t-Statistic \\
\hline$\Delta$ LFDI & 0.046072 & $2.468048^{* *}$ \\
\hline C & 0.063571 & $5.740936^{*}$ \\
\hline
\end{tabular}

(I) Model Criteria / Goodness of Fit

\begin{tabular}{|l|l|}
\hline R-squared & 0.173583 \\
\hline Adjusted R-squared & 0.145086 \\
\hline F-statistic & $6.091259^{*}$ \\
\hline
\end{tabular}

(II) Diagnostic Checking

\begin{tabular}{ll|}
\hline a) Autocorrelation (Breusch-Godfrey Serial Correlation LM Test) \\
\hline F-statistic & $1.503516[0.240381]$ \\
Obs* R-squared & $3.106538[0.211555]$ \\
\hline b) ARCH Test: & $1.755810[0.195860]$ \\
\hline F-statistic & $1.770219[0.183355]$ \\
Obs* R-squared &
\end{tabular}

c) Jarque-Bera $\quad 0.543344[0.762104]$

Estimate Model for the Malaysia Growth Function

II) Estimate Model

Dependent variable: $\triangle \mathrm{LRGNI}$

\begin{tabular}{|l|l|l|}
\hline Variable & Coefficient & t-Statistic \\
\hline$\Delta$ LFDI & 0.044877 & $2.431024 * *$ \\
\hline $\mathrm{C}$ & 0.063488 & $5.797811^{*}$ \\
\hline
\end{tabular}

(I) Model Criteria / Goodness of Fit

\begin{tabular}{|l|l|}
\hline R-squared & 0.169290 \\
\hline Adjusted R-squared & 0.140644 \\
\hline F-statistic & $5.909879 * *$ \\
\hline
\end{tabular}

(II) Diagnostic Checking

\begin{tabular}{|c|c|}
\hline a) Autocorrelation & A Test) \\
\hline F-statistic & $1.181906[0.322065]$ \\
\hline Obs* R-squared & $2.495526[0.287146]$ \\
\hline
\end{tabular}




\begin{tabular}{|ll|}
\hline b) ARCH Test: & \\
\hline F-statistic & $1.641160[0.210676]$ \\
Obs* R-squared & $1.661028[0.197465]$
\end{tabular}

c) Jarque-Bera $0.603123[0.739662]$

Note: Lag length given in ( ) and probability value stated in [ ].

$*, * *$ and $* * *$ indicate significant at $0.1,0.05$ and 0.01 marginal level.

For Breusch-Godfrey Serial Correaltion LM Test, we are testing for correlation at the 0.05 significant level.

For ARCH Test, we are testing for heteroscedasticity at the 0.05 significant level.

The result from diagnostic checking show the model does not suffer from autocorrelation and heteroscedasticity and the series is normally distributed. It can conclude that result from both equations are reliable, where their computed $\mathrm{t}$-statistics are greater than $\mathrm{t}$-critical value in 5 percent level, therefore, we can conclude that there is sufficient evidence to show that there are significant relationship between economic growth and foreign direct investment inflows (FDI) in Malaysia. Since the sign is positive, so there is positive relationship between these two variables in Malaysia. FDI has direct positive impact on RGDP because when FDI rate increase by $1 \%$, this will lead the growth rate increase by $0.046072 \%$. Furthermore, FDI has direct positive impact on RGNI because when FDI rate increase by $1 \%$, this will lead the growth increase by $0.044877 \%$. Therefore, the results obtained are consistent with our expected results, which mentioned in the previous section, where FDI inflows will contribute to the economic growth in Malaysia.

\section{Conclusion}

As a conclusion, foreign direct investment has continued to play a significant role in the Malaysia's economy. Through the empirical result, the analysis shows that there is a positive relationship between the FDI and economic growth, which the relationship is found to be significant. The robustness of the result has been test using GNI as dependent variable. These findings have important policy implication where the government has to concern the importance of the FDI contributed to economic growth. Economy development of a country can be achieve by encourage more foreign direct investment, which it can help to create more employment in the country. In addition, advance technology in production will trained more skilled labor; therefore it will enhance the productivity and fulfil the satisfaction and demand from the consumers. But, there is negative effect on domestic producer, because they losing the market power, since the foreign investor become monopoly in the market. This indirectly will make the domestic producer facing the difficulties to survive in the market in the long term as foreign companies can achieve economy of scale with advance technology.

Therefore, government should impose the relevant policies likes joint venture in order to give opportunities to the domestic producer become one of the part and enjoy the profit together with foreign direct investors. This will benefit to local partner as they are expose to higher technology. Besides, government plays an important role in maintaining political stability. Because if a new government come in with highly different policies, foreign direct investors need to adjust their strategies in accordance with those new policies. In some cases, bribery may start and causing higher costs to investors. This will decelerate the growth in a country. Furthermore, economic instability likes higher inflation and fluctuation in exchange rate in a country also one of the important factor to discourage foreign direct investments.

\section{Reference}

Akaike, H. 1973. Information theory and the extension of the maximum likelihood principle, in B. N. Petrov and F. Csaki, eds. Proceedings of the Second International Symposium on Information Theory, Budapest, 267-281.

Balasubramanyam, V. N. \& Salisu, M. \& Dapsoford, D. 1996. Foreign direct investment and growth in EP and IS countries. Economic Journal, 106,. 92-105.

Bengoa, M. \& Sanchez-Robles, B. 2003. Foreign direct investment, economic freedom and growth: new evidence from Latin America. European Journal of Political Economy, 19, 529-545.

Borensztein, E. \& De Gregorio, J. \& J.W. Lee. 1998. How does foreign investment affect growth?. Journal of International Economics, 45.

Carkovic, M. \& Levine, R. 2002. Does foreign direct investment accelerate economic growth? Working paper of University of Minnesota. Source: http://www.worldbank.org/research/conferences/financial_globalization/fdi.pdf. Access date: 8 August 2007.

Choe, J.I. 2003. Do foreign direct investment and gross domestic investment promote economic growth? Review of Development Economics, 7(1), 44-57

Chowdhury, A \& Mavrotas. 2003. FDI and growth: What cause what?. WIDER conference on 'Sharing Global Prosperity'. 
Culver, E. S., \& Papell, H. D. 1997. Is there a unit root in the inflation rate? Evidence from sequential break and panel data models. Journal of Applied Econometrics, 12, 435-444.

De Mello, L. 1999. Foreign direct investment led growth: Evidence from time-series and panel data. Oxford Economic Papers, 51, 133-151.

Engle, R. F., \& Granger, C. W. J. 1987. Co-integration and error correction:Representation, estmation and testing. Econometrica, 55, 1-87.

Frimpong, J. M \& Abayie, E. F. O 2006. Bivariate causality analysis between FDI inflows and economic growth in Ghana.

Granger, C. W. J. 1986. Development in the study of cointegrated economic variables. Oxford Bulletin of Economics and Statistics, 48, 213-228.

Kwiatkowski, D., P. Phillips, P. Schmidt, \& Y. Shin. 1992. Testing the null hypothesis of stationarity against the alternative of a unit root. Journal of Econometrics, 54, 159-178.

Mackinnon, J. 1991. Critical values for cointegration tests. In R. F. Engel and C. W. J. Granger, eds, long run economic relationships: Readings in cointegration, Oxford: Oxford University Press.

Mohd, N. I. 2001. Foreign direct investment and development: The Malaysian electronics sector. WP 2001:4. Chr.Michelsen Institute Development Studies and Human Rights.

Newley, W. K., \& West, K. D. 1987. A simple, positive semi-definite, heteroscedasticity and autocorrelation consistent covariance matrix. Econometrica, 55, 703-708.

Olofsdotter, K. 1998. Foreign direct investment, country capabilities and economic growth, Weltwirtschaftliches Archiv, 134(3), 534-547

Phillips, P. C. B., \& Perron, P. (1988). Testing for unit root in time series regression. Biometrica, 75, 335-346.

United Nations Conference on Trade and Development (UNCTAD). 2003. World investment report. Various issues.

West, K. D. 1988. On the interpretation of near random walk behavior in GNP. American Economic Review, 78, 202-209.

Zhang, K.H. 2001. Does foreign direct investment promote economic growth? Evidence from East Asia and Latin America, Contemporary Economic Policy, 19(2), 175-185 